\title{
ANALYSIS OF CHARACTERISTIC NEWS CONTENT AND ACCURACY IN ONLINE JOURNALISM \\ (Rape Case by Reynhard Sinaga on Tirto.id News Portal)
}

\author{
Icha Rochmah Maghrifi \\ Jl. Puspita Jaya, Jenangan, Ponorogo \\ Institut Agama Islam Negeri Ponorogo \\ icha.rmaghrifi1605@gmail.com
}

\begin{abstract}
The development of information and communication technology is marked by the increasing use of online media. The presence of the internet that is used as the Internet of Things (IoT) or the Internet for Everything makes people more often use the internet, especially in meeting their needs, one of the needs of fulfilling information. Online journalism is one of the latest breakthroughs in the world of journalism that can fulfill information for the public through the internet. However, online journalism is often regarded as a news media that is fixed at one point of necessity, namely speed. The inevitability of online journalism is often in the spotlight because it is considered to sacrifice the basic principles of journalism, especially the accuracy of news for the sake of speed. In connection with the Reynhard Sinaga case which is quite complicated, and has just appeared in the media including Tirto.id. Therefore this research formulates the problem and aims to find out: (1) news characteristics of the Reynhard Sinaga case in the Tirto.id portal and (2) the accuracy level of the news of the Reynhard Sinaga case in the Tirto.id news portal. This research uses descriptive research with a descriptive quantitative approach, which analyzes the characteristics and accuracy of news related to the Reynhard Sinaga case in the portal Tirto.id. Researchers get the data of news from the documentation directly in the Tirto.id website. The results of this study conclude that (1) the news characteristics of the Reynhard Sinaga case in the Tirto.id portal are in accordance with theories relating to the characteristics of online journalism which always emphasizes the important principle of immediacy or freshness of news and multimedia or the diversity of formats in news delivery. (2) the accuracy of the news published by Tirto.id which is assessed from 5 categories of accuracy assessment shows that the news contained in the portal can be considered accurate. With an accuracy value above fifty percent.
\end{abstract}

Keywords: Content Analysis, Characteristics, News, Accuracy, Tirto.id.

\section{INTRODUCTION}

The development of information and communication technology is marked by the presence of online media. Civilization changes so fast as technology develops. The presence of the internet that can contribute to all aspects of human life makes the internet the tool most often used in their lives. People no longer need to go to a 
distant place just to see the beach, because the internet provides all the information related to this. Likewise housewives, now they no longer need to buy cookbooks because the internet now provides them. The popularity of the internet is the starting point for conventional / print journalistic media to experience a decline in interest.

In the United States, many people have neglected the newspapers that were once the main news source. This is in line with information that The Rocky Mountain News in Denver was forced to close after 150 years of publication. ${ }^{1}$ TRMN's closure is nothing but the last resort that companies should make to cut their budgets due to a lack of revenue from advertising or customer fees. After the proliferation of online media, in Indonesia, the number of companies that still survive publishing newspapers is not as many as before. Media companies that still print newspapers are also dominated by large companies such as the Jawa Pos Group, Kompas Gramedia, Koran Sindo, and several other regional newspaper companies that have persisted despite their declining circulation. ${ }^{2}$ Based on data from the Press Council, until 2019 the number of online media in Indonesia counted as many as 47,000, with2,700 verified media ${ }^{3}$, Meanwhile, the number of surviving printed media and verified based on data from the Press Council is 545 newspapers. ${ }^{4}$

In a four-year survey conducted by Nielsen Holdings, a communication, information, and media research company, with the headline Nielsen Consumer and Media View (CMV) Q3 2017, the survey results show the percentage of print media readers in Indonesia has an age range of 20-49 years with a profile work as employees and the majority come from the upper class. The results of the CMV Q3 2017 survey also revealed that the number of online media readers in Indonesia has reached six million people with a penetration of $11 \%$, in other words, this percentage can be said to be more than the penetration of newspapers which is only $8 \%$. Based on the same survey, the frequency of internet use among readers of print media reached 86\%. Hellen Katherina as the Executive Director of Nielsen Media said that with the results of such a survey, it can be concluded that people's interest in reading, especially in newspapers has not decreased but only changed platforms, from a print platform to a digital platform. ${ }^{5}$

IThe deteriorating climate of print, newspapers have forced newspaper publishing to switch to online media. Kompas.com, which was originally created

\footnotetext{
${ }^{1}$ Richard Perez-Pena, Rocky Mountain News Fails to Find Buyer and Will Close, dikutip dari https://www.nytimes.com/2009/02/27/business/media/27paper.html/ diakses pada 27 Januari 2020.

${ }^{2}$ http://harnas.co/2019/02/10/berlalunya-masa-keemasan-agen-koran diakses pada 18 Mei 2020.

${ }^{3}$ https://amsi.or.id/dari-47-ribu-baru-2-700-media-online-terverifikasi-dewan-pers/ diakses pada 18 Mei 2020.

${ }^{4}$ https://dewanpers.or.id/data/perusahaanpers?m=1 diakses pada 18 Mei 2020.

${ }^{5}$ https:// www.nielsen.com/id/en/press-releases/2017/media-cetak-mampu-

mempertahankan-posisinya/diakses pada 18 Mei 2020.
} 
only to anticipate the rise of online mass media, is now actually successful with its online media. Other online media such as Tempo.co, Detikcom, Okezone.com are also successful with their news published in online media. This fact illustrates that in the future, new media will increasingly play a role, followed by strong community participation.

The development of online media in Indonesia from year to year has a serious impact on the construction of reporting on sexuality in a news story. Wood explained that sexuality is a profitable object for the media to be commercialized and exploited. So far, online media coverage that contains elements of sexuality has often attempted to provide fantasy and image satisfaction to rape newsreaders. This effort is manifested through detailing rape narratives in a story so that the reader's emotions seem to be stimulated and led to the same situation. According to Wood, in understanding cases of sexuality that are presented in a news, the media tends to be biased in representing the victim as a weak figure and very precisely in the position of playing the victim. ${ }^{6}$ This confusion of perspective causes the media to circulate in the framework of the capitalization of acts of sexuality cases. The media do not care and are insensitive to cases of sexuality and sexuality is only used as an interest in increasing the number of visits.

The problem of the ambiguity of delivering news entitled sexuality in the media is indeed a matter that is discussed quite often. In fact, the media, which should provide neutral information about sexuality, mostly provide detailed and detailed narratives and explanations that have the potential to harm victims or actually encourage more acts of sexual violence or what is often referred to as copycat crime. Copycat crimes or crimes committed because they are motivated or inspired by media reports often occur and are recognized by criminal suspects. ${ }^{7}$ The case of sexual violence with the copycat crime motive has also occurred in Indonesia, to be precise in Manado in June 2016. In this case, the suspect with the initials FS admitted to having committed violence against his girlfriend with the initials I because he was motivated by the reporting of the EF case that occurred in Tangerang last month. May of the same year. ${ }^{8}$ In this study, the author deliberately raised the case of rape committed by Reynhard Sinaga in the hope that the researcher could see changes in the delivery of information about the case in the media, especially Tirto.id. The hope of this change in delivery is based on the policy of the British District Court which revealed Reynhard Sinaga's case to the media after going through three years of investigation and four trials until the case was finally final.

\footnotetext{
${ }^{6}$ Julia T. Wood, Gendered Lives: Communication, Gender, and Culture (Boston: Wadsworth Publishing, 2005), 215-223.

7 http://youthproactive.com/201606/perspektif/media-dan-kekerasan-seksual/_diakses pada 25 Januari 2020.

${ }^{8}$ https://solo.tribunnews.com/2016/06/07/pelaku-pemerkosaan-sadis-di-manadomengaku-meniru- kasus-ef-di-tangerang diakses pada 25 Januari 2020.
} 
From this, the researcher wants to examine how many mistakes have been made by the media, especially Tirto.id in conveying the accuracy and characteristics of the news entitled the case of rape by Reynhard Sinaga.

In this research, the writer will conduct descriptive quantitative content analysis to see to what extent the characteristics and accuracy of the news contained in the Tirto.id news portal with the categorization method adapted from the theory of Media Performance, MqQuail's idea which is also applied in research that has been conducted by the Press Council in research. coverage of 28 newspapers in Java in 2004. ${ }^{9}$ This research is also based on research that has been uploaded in the Pekommas Journal belonging to the Makassar Center for the Study and Development of Communication and Information (BBPPKI) written by Christiany Juditha with the title "News Accuracy in Online Journalism (Alleged Case of Corruption by the Constitutional Court on the Detiknews News Portal). "10 In his research, the author explains the current state of journalism which often sacrifices the basic principles of journalism such as news accuracy to catch up with speed. This research uses content analysis that focuses on news related to the alleged corruption case of the Constitutional Court, particularly on the news portal detikNews. The results of the research examined by the author indicate that the detikNews.com portal is considered accurate. This can be seen from the quantitative results of the five categories of news accuracy that are worth more than $50 \%$.

Online journalism as the latest breakthrough in the world of journalism is often regarded as a news media that is fixated on one point of necessity, namely speed. The necessity of online journalism is often in the spotlight because it is considered to be sacrificing basic journalistic principles, especially news accuracy to catch up with speed. Objectivity values such as accuracy, fairness, completeness, and impartiality in the news are considered to be sidelined for the sake of speed.

Tirto.id is a new online news portal that has entered the realm of journalism for the first time in the new media era. Previously, the Tirto news portal had never produced news in the form of a newspaper. Tirto.id can be said to be a new online media portal that has emerged with its unique news which is different from other online media news portals. Almost all news published on the Tirto.id portal is always presented in several types, namely, text, infographics, and videos. Tirto.id can display an interesting mix of news texts and infographics. The presentation of the infographic is what makes Tirto.id synonymous with infographics. Reporting from the news "Celebrating Two Years of Tirto.id's Age with Infographics" 11 which was published in his portal on August 3, 2018, Tirto.id said that his media was not the first media to use infographics.

\footnotetext{
${ }^{9}$ Rachmat Kriyantono, Teknis Praktis Riset Komunikasi (Jakarta: Kencana Prenada Media Group, 2004) 239.

10 https://media.neliti.com/media/publications/222363-akurasi-berita-dalam-jurnalisme-online-k.pdf diakses pada 9 Maret 2020.

${ }^{11}$ https://tirto.id/merayakan-dua-tahun-usia-tirto-dengan-infografik-cQo5 diakses pada 25 Januari 2020.
} 
The consistency and massiveness of Tirto.id in presenting the infographics on the news is what makes the writer interested in researching the news presented by Tirto.id. To limit the analysis, the writer chooses the news on the Tirto.id portal with the topic of Reynhard Sinaga's Rape Case.

The research method used to determine the accuracy of the news about Reynhard's case, the researcher used a descriptive quantitative research approach. This method is expected to provide a better understanding of the problem to be studied. This method is expected to provide a stronger conclusion-making process. The descriptive quantitative method will provide power about the issues discussed so that it is expected to produce better conclusions.

In this research, the main object that will be the focal point is the news related to the Reynhard Sinaga case which is published in the Tirto.id news portal. News related to the object of this research in the Tirto.id portal has been used as a topic of discussion, with a total of 12 news. The news is published from January 7 to January 15,2020 . Data analysis is the process of finding and compiling from the results of data obtained from documentation, case studies, and other materials so that they can be easily understood. ${ }^{12}$

In this research, the writer used a descriptive quantitative content analysis method (with frequency quantification). Content analysis is a summarizing activity, the quantification of messages is based on the scientific method by processing data through the SPSS program. The results of the analysis will be in the form of a frequency table which will be described descriptively. ${ }^{13}$

\section{Analysis Of Characteristic News Content And Accuracy In Online Journalism}

Technological developments bring the media into a new change. These changes are commonly referred to as new media. New media provide ample opportunity for the public to access news via the internet network. The new media in question is the practice of online journalism or journalism that uses internet connectivity in the process of disseminating news. In its application, each online news portal has its characteristics.

The following are the characteristics of news related to the Reynhard Sinaga case in the online media portal Tirto.id which is in accordance with the theory of online journalistic characteristics according to Mike Ward (1) Freshness or speed of information delivery (immediacy). At this point, Tirto.id has not applied the immediacy factor in delivering information. This is evidenced by a news post entitled Reynhard Sinaga in Prison for Life, Rape of Hundreds of Men in the UK which was uploaded 6 hours after the first news about this case was reported by The Guardian on January 6, 2020, at 14:23 GMT or 21:23 WIB after Judge Suzanne

\footnotetext{
${ }^{12}$ Sugiyono, Metode Penelitian Kuantitatif Kualitatif dan $R \& D$ (Bandung: Alafabeta, 2015), 244.

${ }^{13}$ W Lawrence Neundorf, The Content Analysis Guidebook (Thousand Oaks: Sage Publications, 2002), 10.
} 
Goddard issued a verdict regarding the Reynhard Sinaga case on Monday, January 6,2020 . Another reason that proves Tirto.id was slow in this case is the news uploads in other online media such as Kumparan and BBC Indonesia which have been released on the same day after the verdict hearing. (2) News is composed of many pages (page) and connected to each other (multiple paginations). In every news page, Tirto.id related to this case has implemented a hyperlinked system that is interconnected between news and news sources. The following is a list of news that contains the context of the link (hyperlinked)

Table 1

News List Containing Links ${ }^{14}$

\begin{tabular}{|c|l|l|}
\hline No. & \multicolumn{1}{|c|}{ News Title } & \multicolumn{1}{|c|}{$\begin{array}{c}\text { Number of Link } \\
\text { Links }\end{array}$} \\
\hline 1. & $\begin{array}{l}\text { Reynhard Sinaga Imprisoned for Life, Rape } \\
\text { Hundreds of Men in England }\end{array}$ & 3 links \\
\hline 2. & $\begin{array}{l}\text { The Foreign Ministry Affirms the } \\
\text { Indonesian Embassy to Always } \\
\text { Accompany Reynhard during the Trial }\end{array}$ & 3 links \\
\hline 3. & $\begin{array}{l}\text { Reynhard Sinaga Rape Case in England \& } \\
\text { Response of the Indonesian Embassy in } \\
\text { London }\end{array}$ & 2 links \\
\hline 4. & $\begin{array}{l}\text { Reynhard Sinaga's Case Becomes the Worst } \\
\text { Rape in British History }\end{array}$ & 5 links \\
\hline 5. & $\begin{array}{l}\text { Reynhard Sinaga, Rapist of 136 Male in } \\
\text { England Sentenced to Life }\end{array}$ & 2 links \\
\hline 6. & $\begin{array}{l}\text { Get to know the GHB drugs used for } \\
\text { anesthesia during rape }\end{array}$ & 5 links \\
\hline 7. & $\begin{array}{l}\text { Polri will check Reynhard Sinaga's criminal } \\
\text { records }\end{array}$ & 3 links \\
\hline 8. & $\begin{array}{l}\text { Reynhard Sinaga, UK's Most Evil Rapist } \\
\text { from Indonesia }\end{array}$ & 8 links \\
\hline 9. & $\begin{array}{l}\text { Reynhard Sinaga's Case: Sexual Violence } \\
\text { Does Not Know Your Sexual Orientation }\end{array}$ & 9 links \\
\hline 10. & $\begin{array}{l}\text { If the Reynhard Sinaga case occurs in } \\
\text { Indonesia }\end{array}$ & 4 links \\
\hline 11. & $\begin{array}{l}\text { Indonesian Campus Should Learn from the } \\
\text { Reynhard Sinaga Case }\end{array}$ & 10 links \\
\hline 12. & $\begin{array}{l}\text { Raids on LGBT, the Mayor of Depok, Only } \\
\text { Worsens Stigma and Discrimination }\end{array}$ & 6 links \\
\hline & & \\
\hline
\end{tabular}

\footnotetext{
${ }^{14}$ https://tirto.id/topik/kasus-pemerkosaan-oleh-reynhard-sinaga-5e1419d0c1f8ca21f0b 6f7bb diakses 20 April 2020.
} 


\begin{tabular}{|c|l|l|}
\hline 13. & $\begin{array}{l}\text { Not only women, but men can also be } \\
\text { victims of rape }\end{array}$ & 8 links \\
\hline 14. & $\begin{array}{l}\text { Reynhard Sinaga's Schemes of Crime and } \\
\text { the 'Intelligence' Factor }\end{array}$ & 9 links \\
\hline
\end{tabular}

(3) News contains information in the form of text, audio, image, video, or a combination of the two or more (multimedia). In the published news, Tirto.id has implemented a multimedia component consisting of a combination of text, photos, illustrations, and infographics. (4) Journalists can write as well as deliver news anytime and anywhere (flexibility delivery platform). In its work system and practice, Tirto.id applies an online system in news delivery and processing. Journalists can write their news online anywhere and anytime which is then sent to the editorial desk via electronic mail (email) via the address redaksi@tirto.id. (5) Stored news, archived, and can be accessed at any time (archiving). Tirto.id has implemented an archive system in each related news topic. An example is the archive of the news on the Reynhard Sinaga case which is packaged in the topic of Reynhard Sinaga's Rape Case, which can be accessed directly on one page. The following is a page that presents news related to the Reynhard Sinaga case. (6) Allows the participation or interaction of readers directly through the comments column (relationship with readers). In its news portal page, Tirto.id has not implemented the comment column function to increase participation or interaction from readers. However, Tirto.id applies a news subscription service to readers via email. Readers can also contribute articles to the Mild Report Index, by sending their writing to the Tirto.id editorial desk via electronic mail (email) redaksi@tirto.id with email subject [Mild Report] which explains in detail the procedure in the FAQ tab (Frequently Asked Requested).

\section{Analysis Of Characteristic News Content And Accuracy In Online Journalism}

According to Singarimbun and Effendi, the reliability test is an index that shows the extent to which a measuring instrument is reliable or reliable. If a measuring device is used twice, to measure the same symptoms and the measurement results are obtained relatively consistent, then the measuring device is reliable. In other words, reliability shows the consistency of a measuring device in the same symptom gauge.

In this study, researchers have tested the reliability of the coding sheets used. This test uses a due coder with a total of 14 news samples, the researcher uses all the news as the sample used in the reliability test.

Table 2

Accuracy Assessment Category ${ }^{15}$

\footnotetext{
${ }^{15}$ Rachmat Kriyantono, Teknis Praktis Riset Komunikasi (Jakarta: Kencana Prenada Media Group, 2007), 239 - 240.
} 


\begin{tabular}{|c|l|c|}
\hline No. & \multicolumn{1}{|c|}{ Variable } & $\begin{array}{c}\text { Percentage } \\
\text { Approval }\end{array}$ \\
\hline 1. & $\begin{array}{l}\text { Checks and checks (checks and checks back on } \\
\text { news sources) }\end{array}$ & $75 \%$ \\
\hline 2. & $\begin{array}{l}\text { Written errors in data, dates, names of sources, } \\
\text { addresses and so on. }\end{array}$ & $75 \%$ \\
\hline 3. & $\begin{array}{l}\text { Relevant news sources (news sources that match } \\
\text { the current events) }\end{array}$ & $75 \%$ \\
\hline 4. & $\begin{array}{l}\text { Accuracy of title with content (title and content } \\
\text { are related) }\end{array}$ & $70 \%$ \\
\hline 5. & $\begin{array}{l}\text { Accuracy between photos and content (photos or } \\
\text { images presented are related and support news } \\
\text { content) }\end{array}$ & $75 \%$ \\
\hline
\end{tabular}

Description of Research Results Analysis of News Accuracy

a. Category Check and Check-in News Sources

Table 3

Results of Check and Check Data Processing

\begin{tabular}{|c|c|c|c|c|c|}
\hline \multirow{3}{*}{ Valid } & Frequency & Percent & $\begin{array}{c}\text { Valid } \\
\text { Percent }\end{array}$ & $\begin{array}{c}\text { Cummulativ } \\
\text { e Percent }\end{array}$ \\
\hline & No & 2 & 14.3 & 14.3 & 14.3 \\
\cline { 2 - 6 } & Yes & 12 & 85.7 & 85.7 & 100.0 \\
\cline { 2 - 6 } & Total & 14 & 100.0 & 100.0 & \\
\hline
\end{tabular}

Based on the table above, it shows that all the news published in the online media portal Tirto.id related to the Reynhard Sinaga case, there are 2 news stories or $14.3 \%$ of 14 news stories that do not check and check with news sources. Meanwhile, the remaining 12 news or $85.7 \%$ of the 14 news items have been checked and checked.

To determine the credibility of the media in the eyes of the public, accuracy is one of the most basic benchmarks. The inaccuracies that often appear in news in online media today occur due to the lack of checking and checking of news sources. Check and check can be interpreted as the process of checking and checking back on news sources. Accuracy indicates the need for verification of facts/information.

Of the many parameters used in measuring accuracy, the issue of verification of facts and accuracy of presentation has become a major problem in several media. Verification of facts provides an understanding of the extent to which the news displayed corresponds with the facts that happened in the field. 
b. Writing Error Category

Table 4

Results of Writing Error Data Processing

\begin{tabular}{|c|c|c|c|c|c|}
\hline & & Frequency & Percent & $\begin{array}{c}\text { Valid } \\
\text { Percent }\end{array}$ & $\begin{array}{c}\text { Cummulative } \\
\text { Percent }\end{array}$ \\
\hline \multirow{3}{*}{ Valid } & No & 9 & 64.3 & 64.3 & 64.3 \\
\cline { 2 - 6 } & Yes & 5 & 35.7 & 35.7 & 100.0 \\
\cline { 2 - 6 } & Total & 14 & 100.0 & 100.0 & \\
\hline
\end{tabular}

Based on the table above, it shows that all the news contained in the online media portal Tirto.id related to the Reynhard Sinaga case, there are 9 news stories or $64.3 \%$ news that do not have writing errors, both data, names of sources, addresses and so on. Meanwhile, the remaining 5 news or $35.7 \%$ of the news had writing errors.

Accuracy assessment categories included in writing errors in the news include data, dates, names of sources, addresses, and so on. The results showed that in general, Reynhard Sinaga's case had many writing errors with a percentage of $5 / 14$. Of the 14 news items presented, there were 5 items containing writing errors. Generally, writing errors occur in sentences containing scientific verbs and names.

c. Relevant News Sources Category

Table 5

Results of Processing Data Relevant News Sources

\begin{tabular}{|c|c|c|c|c|c|}
\hline & & Frequency & Percent & $\begin{array}{c}\text { Valid } \\
\text { Percent }\end{array}$ & $\begin{array}{c}\text { Cummulative } \\
\text { Percent }\end{array}$ \\
\hline \multirow{3}{*}{ Valid } & No & 0 & 0.0 & 0.0 & 0.0 \\
\cline { 2 - 6 } & Yes & 14 & 100.0 & 100.0 & 100.0 \\
\cline { 2 - 6 } & Total & 14 & 100.0 & 100.0 & \\
\hline
\end{tabular}

Based on the table above, it shows that all news published in the online media portal Tirto.id related to the Reynhard Sinaga case, all news, namely 14 news or $100 \%$ news, presents sources that are in accordance with the events that are happening. The relevant news source is the suitability of the selection of sources in accordance with the events that are happening. The results of the research described in the results table show that the news of the Reynhard Sinaga Case published in the Tirto.id news portal includes suitable news sources..

d. Category of News Content and Title Accuracy 
Table 6

Results of Data Processing of Title Accuracy and News Content

\begin{tabular}{|c|c|c|c|c|c|}
\hline & & Frequency & Percent & $\begin{array}{c}\text { Valid } \\
\text { Percent }\end{array}$ & $\begin{array}{c}\text { Cummulative } \\
\text { Percent }\end{array}$ \\
\hline \multirow{3}{*}{ Valid } & No & 0 & 0.0 & 0.0 & 0.0 \\
\cline { 2 - 6 } & Yes & 14 & 100.0 & 100.0 & 100.0 \\
\cline { 2 - 6 } & Total & 14 & 100.0 & 100.0 & \\
\hline
\end{tabular}

Based on the table above, it shows that all news published in the online media portal Tirto.id related to the Reynhard Sinaga case, there are 14 news stories or $100 \%$ of all news that have accuracy or compatibility between the title and the news content. From the observation of news on the Tirto.id portal, all news related to the Reynhard Sinaga case has a title and content related to it.

e. Photo Accuracy Category and News Content

Table 7

Results of Photo Accuracy Data Processing and News Content

\begin{tabular}{|c|c|c|c|c|c|}
\hline & & Frequency & Percent & $\begin{array}{c}\text { Valid } \\
\text { Percent }\end{array}$ & $\begin{array}{c}\text { Cummulative } \\
\text { Percent }\end{array}$ \\
\hline \multirow{3}{*}{ Valid } & No & 0 & 0.0 & 0.0 & 0.0 \\
\cline { 2 - 6 } & Yes & 14 & 100.0 & 100.0 & 100.0 \\
\cline { 2 - 6 } & Total & 14 & 100.0 & 100.0 & \\
\hline
\end{tabular}

Based on the table above, it shows that all news published in the online media portal Tirto.id related to the Reynhard Sinaga case, there are 14 news stories or $100 \%$ of all news which are accurate and in accordance with the content of the news. The accuracy between the photo and the content is the last accuracy category. Where in a news story, the photo in the headline should be the original photo or illustration photo related to the events that occurred.

These results then conclude that the Tirto.id online portal in the decision-making process is carried out quickly without forgetting the principles of accuracy in every news element. Accuracy is an ethical standard in addition to professional and operational standards that must be applied and taken into account by journalists in obtaining and processing news/information. ${ }^{16}$

\section{CONCLUSION}

${ }^{16}$ Luwi Ishwara, Catatan-catatan Jurnalisme Dasar (Jakarta: Kompas Media Nusantara, 2008), 13. 
Based on the above analysis, the following conclusions can be drawn. First, as a large online journalism media, Tirto.id has upheld the characters that must be fulfilled in writing news/information on online journalistic media. This can be seen from the character of Tirto.id's news offerings which have displayed aspects of the basic character of online journalism such as freshness of news or speed of information delivery (immediacy), news composed of many pages and connected to one another (multiple). pagination), contains information in the form of text/images/audio/video or a combination of the two (multimedia), journalists can write and deliver news anytime and anywhere (flexibility delivery platform), the news is stored and archived (archiving) and the last is to allow the participation or interaction of readers (relationship with readers).

Second, from all aspects of these characteristics, all news has complete value or it can be said that the Tirto.id portal has delivered the news with the characteristics of online journalism media contained in the theory except in the immediacy aspect. This exception is in accordance with the results of the researcher's observations which prove that the speed of information delivery related to the Reynhard Sinaga case is slower than other media, which is 1 day different.

Third, in the next analysis, the results of the evaluation of the accuracy of the reports of the Reynhard Sinaga case presented by Tirto.id include checks and checks; writing errors in data; relevant news sources; the accuracy of title with content; accuracy between photos and news content; with varying values with a percentage of the value above $50 \%$. Thus, Tirto.id has implemented a standard of characteristics and accuracy in writing its news.

\section{REFERENCES}

https:/ /amsi.or.id/ dari-47-ribu-baru-2-700-media-online-terverifikasi-dewan-pers/ diakses pada 18 Mei 2020.

https:/ / dewanpers.or.id/data/perusahaanpers?m=1 diakses pada 18 Mei 2020. https:/ / harnas.co/2019/02/10/ berlalunya-masa-keemasan-agen-koran diakses pada 18 Mei 2020.

https://media.neliti.com/media/publications/222363-akurasi-berita-dalam jurnalisme-online-k.pdf diakses pada 18 Mei 2020.

https:/ / solo.tribunnews.com/2016/06/07/ pelaku-pemerkosaan-sadis-di-manadomengaku-meniru-kasus-ef-di-tangerang_diakses pada 18 Mei 2020.

https:// tirto.id/merayakan-dua-tahun-usia-tirto-dengan-infografik-cqo5_diakses pada 18 Mei 2020.

https://www.nielsen.com/id/en/press-releases/2017/media-cetak-mampumempertahankan-posisinya/_diakses pada 18 Mei 2020.

https://www.nytimes.com/2009/02/27/business/media/27paper.html/ diakses pada 27 Januari 2020.

https:/ /youthproactive.com/201606/perspektif/media-dan-kekerasan-seksual/ . diakses pada 18 Mei 2020. 
Ishwara, Luwi. Catatan-catatan Jurnalisme Dasar. Jakarta: Kompas Media Nusantara, 2008.

Kriyantono, Rachmat. Teknis Praktis Riset Komunikasi. Jakarta: Kencana Prenada Media Group, 2007.

Neundorf, W Lawrence. The Content Analysis Guidebook. Thousand Oaks: Sage Publications. 2002.

Sugiyono. Metode Penelitian Kuantitatif Kualitatif dan $R \mathcal{E} D$. Bandung: Alafabeta, 2015.

Wood, Julia T . Gendered Lives: Communication, Gender, and Culture. Boston: Wadsworth Publishing, 2005. 